The Geneva Papers on Risk and Insurance, 22 (No. 84, July 1997) 392-399

\title{
A Pioneer's View of Financial Services Negotiations in the GATT and in the World Trade Organization: 17 Years of Work for Something or Nothing?
}

\author{
by Harry L. Freeman*
}

The first serious push for some kind of trade regime for financial services in the GATT was made by the American International Group (AIG) during the Tokyo Round in the mid to late 1970's. AIG was having difficulties entering some of the Asian insurance markets and worked with the then United States Trade Representative (USTR), Robert Strauss, to address their issues. Although "services" was too new an issue for the Tokyo Round, Strauss was successful in getting the term "services" within a new and broader definition of "trade" in US law. This turned out to be a very significant marker in later years.

In 1978 American Express Company (Amex) joined AIG in the effort to open services markets (with particular emphasis on financial services markets), by securing a place for services in any new multilateral trade talks. Amex businesses were broader than traditional definitions of "banking, securities and insurance". It decided that it stood a better chance of securing liberalization of its own businesses if it sought to seek liberalization of all trade in services rather than just its own parochial interests.

Inclusion of services in a traditional trade round took years of effort. Many trade professionals thought services as a trade issue might crowd out concurrent tariff negotiations over goods, i.e. many feared getting into trade in services in the Uruguay Round since the Round would be difficult enough with tariff cutting on goods and negotiations in such areas as agriculture.

When services were finally included in the Uruguay Round in 1986, it was considered a minor matter. Eleven years later, 1997, it is hard to think of any trade negotiations of consequence as not including trade in services. Services trade has come a long way in a relatively short time.

Amex began its efforts to expand services trade and had a strong motive for moving into a leading position to liberalize trade in services. It was having serious market access problems in many major countries and markets. Those problems stemmed from the fact that Amex was engaging in financial services activities as a non-bank in countries where typically a handful of very large banks dominated their markets. Amex needed, in each country, nondiscriminatory access to national telecommunications networks and payment systems, both of which were under the influence of its foreign competitors.

\footnotetext{
* President, The Freeman Company, Chevy Chase, Maryland, U.S.A.
} 
After careful examination of the challenge of including services in future trade negotiations, Amex decided to devote substantial funds and senior staff to make an effort to get financial services in the GATT. An initial decision was that in order to get rules on financial services, all other services had to be included in the effort, and a new trade round had to be commenced. This was an uphill battle of major consequence.

Amex was joined, from 1979 on, by a few other corporate giants (notably Citicorp) to take on this new challenge and, together with AIG, they sought to put services on the trade map. A major public and media relations effort was launched and remained in place through most of the 1980's.

One of the first efforts by Amex was to popularize and define the term "financial services", which hardly appeared before 1978. Amex's motive was to seek a broader definition of financial services than simply "banks, securities firms and insurance", since many of Amex activities, while financial in nature, were not included in the traditional terminology. This inclusive approach became critical later when "financial services" were defined in the GATT agreements as "any service of a financial nature". This is an all-inclusive definition of a rapidly changing industry. Opponents wanted to approach financial services with a "positive" list, i.e. "financial services is banking, securities, insurance, etc". In retrospect this open ended definition of financial services was to become more important than its promoters realized at the time.

Amex sought and obtained many forums around the world to push the notion that trade in services should be the subject of GATT negotiations. It helped establish a new trade association, the Coalition of Service Industries, in 1982, and sponsored research in the US and Europe on how to go about including all services in a GATT Round. A formal services advisory committee to USTR was formed with Amex CEO James D. Robinson III as its first Chair. Within a few years Robinson chaired of the very influential Business Roundtable trade task force. By the mid-1980's, Robinson had become chair of the powerful president appointed trade advisory committee to the President (ACTPN). Robinson's Chair of the services advisory committee was assumed for several years by John Reed, CEO of Citicorp.

AIG often worked with Amex in these activities and its CEO, Maurice "Hank" Greenberg, was, and remains, a major player in trade policy. Thus, Robinson, Greenberg and Reed, became the most influential individuals from the US private sector concerning both overall and services trade policy. In fact, their responsibilities went far beyond trade in services and extended to all trade issues. All three favored strong rules for trade in services, particularly financial services. They also favored eliminating tariffs on all goods and were strongly biased towards free trade principles.

In the early 1980's, Amex, AIG and Citicorp worked closely with then USTR Bill Brock, and his successor, Clayton Yeutter, to launch a new trade round including both traditional areas such as tariff reduction as well as services. The advocates of including services in a GATT Round had two challenges (1) making the case around the world for a new trade round in the GATT, and (2) making the case that trade in services be included in that new round.

Those goals were not easily accomplished. The effort to include services and start a new round failed at the 1982 GATT Ministerial, and again in the 1984 GATT ministerial, although ministers agreed to a study on services in the GATT. The major breakthrough 
came in 1986 when the Uruguay Round was launched, and this came to pass largely by the US threat to leave Punta Del Esta, Uruguay, without any agreement. The new round included services almost as an afterthought.

When GATT negotiations in the Uruguay Round actually commenced at the end of 1986, the outlook for a strong deal in any of the services areas, financial services or otherwise, was bleak at best. Apart from the US and some European Union countries, there was little interest. Most GATT member governments had little interest in services. The outlook went from bad to worse in 1987 when the GATTmodel for such a services agreement shifted from a "top down" to a "bottom up" approach. This meant that countries could sign on (or not) as they wished to various parts of any services agreement, rather than automatically sign on to the whole of any services agreement.

One often overlooked factor that turned out to be positive for the inclusion of services in the GATT round was the sheer length of the Uruguay Round. Negotiations were prolonged from late 1986 to December, 1993, with one complete collapse in 1990. Therefore, from 1986 to 1993 many persons, unfamiliar with services at the outset and instinctively negative because of lack of familiarity, changed their views as they became more familiar and comfortable with including services in the Uruguay Round.

The stretch-out in years of the Uruguay Round allowed proponents of services in the GATT plenty of opportunities to make their cases to governments around the world, and also time to get more corporations around the world to join the "services movement". The lapse of time turned out to be a positive particularly for the US proponents of services.

During this period from the late 1980s and early 1990s services received steady support from the USTR and its professional staff. Pioneering work was done earlier in the OECD by Geza Feketekuty. Dick Self, still at USTR, was a stalwart negotiator through the whole period from the mid 1980's on. Others, such as Warren Lavorel, the US coordinator of Uruguay Round negotiations, was a major player. Lavorel is now Deputy Director General of the WTO.

In the last weeks of the Uruguay Round negotiations there were a flurry of activity in all areas and it became obvious, however, that some services, such as tourism and enhanced telecommunications, would make more progress than other services areas such as professional services, basic telecommunications and financial services.

A last minute attempt was made by the US in the last days of the Uruguay Round negotiations in late 1993 to put together a deal to make some recordable progress in financial services. This failed attempt was the harbinger of later difficulties in financial services negotiations. The US wanted substantial liberalization commitments from both developed and developing countries in exchange for binding open the US market to foreign financial services.

US law regarding financial services is one of nondiscrimination: there is virtually no distinction between foreign and domestic financial services providers. An example of the importance of this law is found in the application of NAFTA. All US financial institutions, regardless of the nationality of the owners of those institutions, have the benefits of NAFTA. An important contrast is Canada, where only institutions owned and controlled by Canadians get the benefits of NAFTA provisions. 
Returning to the last days of the Uruguay Round in December, 1993, the tentative commitments of other countries regarding financial services were deemed insufficient by the US delegation, and a financial services deal in the Round appeared dead. At this point the US Treasury representatives in Geneva consulted with representatives of the US financial services industry, and came up with a "last ditch" effort. The US proposed a "two tier" plan whereby the US would bind its open market, but only to those countries which also had substantially or fully open markets. Other countries could join only if they met the open market test proposed by the US. The US proposal was essentially a "two tier" arrangement with open market countries in the top tier and all others in the second tier.

This proposal was roundly attacked by the Director General of GATT, by the EU, other countries, and the media as being "discriminatory" and violating the fundamental nondiscriminatory principle (MFN) of the GATT. The US plan was withdrawn for lack of support.

After the US two-tier plan was rejected in December, 1993, further negotiations in financial services under WTO auspices were scheduled to resume in mid-1995, with the hope that the negotiating parties might then be willing to make improved commitments.

That was not to be. The US Treasury and US private sector lobbied throughout 1994 and early 1995 in East Asia seeking better commitments for the mid-1995 negotiations. The US clearly stated its position going into those negotiations. For the US to bind its financial services market completely open on an MFN basis, it had to see a sufficient "critical mass", in numbers and quality of liberalizing commitments, from both developed and developing countries. Secretary of the Treasury Robert Rubin made this crystal clear in a statement to the Congress on June 8, 1995, just a week before intensive negotiations resumed in the WTO in Geneva. He stated that the US would walk away from an inadequate deal, providing a clear statement from the highest authority of the US position.

As the June 30, 1995, date approached the commitments either tabled or promised did not satisfy the US Treasury. There were satisfactory commitments from most of the developed countries. However many of the developing countries commitments did not meet the minimal standards the US had prescribed. The US, disappointed at those poor commitments, then revised its own commitment. It filed one which has an element of reciprocity, namely: the US intended to remain an open market as required by US law, but reserved the right to limit or condition access to the US market if the home country had significant restrictions. The US threat was hollow since most believed the US Congress would not enact a reciprocity test.

At this point, on June 28, 1995, two days before the scheduled close of negotiations, the EU, led by Sir Leon Brittan, suggested a month's extension of the negotiations while it worked to secure better commitments. The US favored and assisted the EU attempt (a fact not reported in the media), and the necessary consensus was obtained for a month's extension.

Thereafter, the EU did two things: (1) made an effort to secure more favorable commitments from developing countries, which failed; and (2) came to Washington, together with Japan, and asked the US Treasury for "comfort" letters. Those letters went to the EU, Japan, and Switzerland, stating that whatever the US might do in limiting access to its market for foreign providers of financial services, the US market would remain completely open to the EU, Japan and Switzerland. Thus, in mid 1995 the EU and Japan accepted a 
de-facto two-tier system favoring the EU and Japan in the top tier, essentially the same twotier plan that the US Treasury offerred in December, 1993. This event was not in the media accounts.

Regrettably, at least in this author's opinion, the US Treasury did provide those letter assurances. Of course, the letters neither have the force of law, nor are they enforceable in the WTO dispute settlement mechanisms. They do represent, however, political commitments by the US Treasury which are unlikely to be ignored in the future. Two-tierism was established in mid-1995 as a practical matter. Such a two-tier arrangement may reappear in the resumption of financial services negotiations in the WTO this year.

By the end of July, 1995, the EU came up with an "interim agreement" to maintain the status quo until the end of 1997. Formal negotiations commenced in Geneva on April 15, 1997 , and shall finish no later than the end of 1997 . The US signed on as a party to that interim agreement and took an MFN exemption, as did many of the countries signing the interim agreement. Again, a fact not reported in the media.

It is worth repeating the US role in the 1995 controversial negotiations: it was supportive of the EU effort and signed the interim agreement. The media continues to suggest the US "walked out"; not so. The US stated its position and filed its commitment on June 28, 1995, and declared that was its final position.

The core problem, whatever critics of the US might say, has been the same in 1993, 1995, and is the principal problem in 1997: most East and South Asian countries, as well as some key South American countries, are simply opposed to real liberalization in the financial services area.

Critics of the US fail to realize that if the US filed a binding commitment to keep its financial services markets open, it would instantly and irrevocably lose all future leverage to secure commitments for more open markets, particularly in Asia and South America.

This view, that the US should hold out for a minimum critical mass of sufficient commitments, is clearly stated in papers issued by the Financial Services Group of the US Coalition of Services Industry, a group of American financial companies formed to promote liberalization of world trade in financial services.

Nevertheless, in 1993 1nd 1995, many Americans in the trade field thought that since the US was, as a practical matter, going to maintain an open market for foreign financial services providers, it might as well file such a commitment, and hand the WTO a "win" and a done deal. At least, the argument ran, the WTO would have some basic deal on which to build in future years.

A major factor in assessing the difficulty of completing any deal in financial services is that finance ministries do most of the negotiating. Heretofore, in GATT Rounds, it has been the trade ministries calling the shots, with the major exception of agricultural negotiations managed by the agricultural ministries, (and hence producing little liberalization in agriculture). The financial services negotiations call upon the world's finance ministries to cede power to the WTO; on its face an uphill challenge. The US Treasury, often criticized by other countries in the financial services negotiations, was in fact ready to cede such power if satisfactory commitments by other countries were filed.

Amidst all of these trade manuevers, what became of Amex, AIG, and Citicorp, the principal US corporate leaders of the 1980's? 
AIG, through Greenberg, and his staff, led in the late 1970's and early 1980's by Ron Shelp, continues to play a major role. AIG's goal was, and remains, attaining market access and the right to have wholly owned subsidiaries in virtually all Asian countries. No one is critical of that goal; although some are dubious as to whether it is attainable in the near to mid-term.

Amex's role continued to expand during the 1980's. I, myself, as Executive Vice President of Amex, accompanied by a high quality staff, played a major role in shaping the Amex strategy and lobbyied hard around the world for services in general and financial services in particular.

Citicorp has now taken over much of the Amex role in trade in financial services. Citicorp's interests are different from both AIG and Amex, in that Citicorp's strategy is to be a consumer bank (i.e. credit and debit cards), as well as a traditional bank, in every major market in the world. Thus, Citicorp has little interest in any deal where it achieves less than full market access. This may be a "hard line" but it is the policy of the US Government at present, and goes to the core of what financial services market access negotiations are all about.

This brings us to late spring. The financial services negotiations resumed in early April, 1997. The US, Canada, and EU private sector groups sent strong teams to the relaunch of talks. Presentations were made on the benefits of major liberalization of financial services, particularly for the emerging and rapidly growing economies of countries in the Pacific Basin. Reports are that ASEAN countries were of a mind to make stronger commitments than in the 1993 and 1995 negotiations, but that has yet to be seen "on the table". It was agreed that the present negotiations would conclude no later than midnight, December 12, 1997; all expect to be in Geneva until that time.

From a US perspective, there was identity between the US Government's position and the those of the US private sector concerned with the negotiations. $1997 ?$

From the perspective of April, 1997, what might we expect at midnight, December 11,

1. Many trade "gurus" argue that no progress can be made on individual subjects in general, and financial services in particular, outside of a broad "round" where "trade offs" between sectors can be made. This is beyond the scope of this paper, except to state that those who call for another broad round to achieve "trade offs" ignore the fact that financial services negotiations are handled by finance ministries which are not given to negotiating trade offs in other areas. It may be that a financial services deal cannot be achieved in 1997; however, it might well be a non-sequitor to then argue that a broad round is necessary to include financial services in any meaningful way.

2. With respect to any progress toward the critical just resumed 1997 negotiations, the US private sector, with the encouragement of the US Treasury, and together with elements of the European and Canadian private sector, is now mounting a major effort to convince the Asian and South American countries to offer better commitments. Much of the effort will be targeted at customers of the banks who would benefit from the competition rather than the existing locally-owned banks who prefer life as it is with less foreign competition. This effort is planned until the negotiations conclude in December 1997. 
3. Many of the Europeans prefer an "incremental" approach where a series of commitments to liberalize are spaced over a long period of years. The US wants commitments to open markets fully, although it will accept reasonable phase-in periods from developing countries. The US disfavors a formal incremental approach since it believes it would have to file, at the outset, a commitment to remain fully open in the first round of incremental negotiations, and thereby cease to have any leverage in securing subsequent improved commitments.

4. There is much sentiment to achieve a "successful" negotiation in terms of maintaining WTO prestige, even if the reality of a deal is less than "successful" in terms of actual liberalization. Many persons forcefully argue that both the successful basic telecommunications negotiations just completed, and the present 1997 financial services negotiations must have a successful harvest by the end of 1997. If not, the argument goes, the chances for other negotiations in both goods and services are greatly reduced. The financial services industry in each country, and their respective finance ministries, do not place a powerful WTO at the very top of their priorities list.

5. On the positive side, the world's financial services markets and providers of financial services are rapidly integrating. The world financial markets are constantly globalizing and financial markets will, over time, either open to foreign competition or find themselves isolated from world capital markets. It may be that the markets themselves will achieve, over time, what negotiations cannot achieve. This suggests that the WTO negotiations themselves may become less important, and that real liberalization will occur regardless of WTO negotiations.

6. Since they dominate financial services, some fairly high level of US-EU cooperation will be necessary to have successful WTO negotiations, along with Japanese concent.

7. Another variable is the identity of US Government officials in the trade area. New high level officials in the trade area are just being identified as this paper is being written. For instance, Jeffrey Shafer, Undersecretary of Commerce for Trade, has left Treasury.

His role is being assumed by Tim Geithner, Principal Deputy, Assistant Secretary of the Treasury, International, Designate; Geithner has been involved in the talks for the last few years, having been in Treasury during Clinton's first term. As of this writing, it appears that the Deputy USTrade Representative, Jeffrey Lang, who has been handling financial services, will continue to do so. There is a new American Ambassador to the WTO, Rita Hayes, whose prior position was the US chief textile negotiator. No doubt there will be changes in other country's negotiating teams. These changes can be quite important in the rollout this year.

The US private sector composition of those arguing for liberalization is also changing. The most recent additions to the US Financial Services Group include such companies as Fidelity (mutual funds), Standard and Poors (financial information), EDS (information processing), and Reuters (financial information). These firms are not engaged in traditional "banking" and they may broaden out the range of issues "on the negotiating table", since their goals may be different from, say, those of Citicorp.

8. There must be a major change in the attitude of many Asian, South American, and other emerging market countries. They must view open markets not as a threat but as a profound economic opportunity. 
9. Since there is little for the US and the EU to "give" to those countries in these negotiations, the necessary attitude change must come from a desire to build the power and prestige of the WTO, rather than any financial services market considerations. Or, some countries may go along in financial services to gain a "trade off" in another area. This might work, but inreasingly "trade offs" are less likely as different ministries with their own political power bases become involved in WTO negotiations.

10. Another possibility is an interim deal with two or three tiers. This system, as mentioned above, now exists between the US and Japan and the EU in one tier, and other countries signatory to the July, 1995, interim agreement in another tier. A third tier might include countries that wish to make no commitment whatsoever in the financial services area. A tier arrangement, plus a new date for further liberalization negotiations, say 1998 or 1999 , remain a distinct possible outcome of the 1997 negotiations.

In this writer's view some "tiered deal" is the most likely outcome of the 1997 negotiations. At the end of the day, such a tiered deal would allow all countries to claim a victory, with the US not bending on its insistence of honoring only open market commitments, a role for countries in the interim stage, and non-participation by countries that want none of any deal.

In sum, we have global financial markets emerging and providing a push for liberalization. We have staked much of the prestige of the WTO on successful financial services negotiations. I predict some deal by the end of 1997.

It may not please all parties, and that may be progress. 